\title{
Pengaruh Demonstrasi terhadap Keterampilan Perawatan Payudara pada Ibu Hamil Trimester Ketiga di Wilayah Kerja Puskesmas Jeulingke Kecamatan Syiah Kuala Banda Aceh Tahun 2018
}

\author{
The Effects of Demonstration on Breast Care Skills in The Third Trimes- \\ ter Pregnant Woman in The Working Area of Jeulingke Community Health \\ Center, Syiah Kuala District, Banda Aceh 2018
}

Ulfa Farrah Lisa ${ }^{1}$ dan Mutia Putri ${ }^{1}$

1) Program Studi D-IV Kebidanan Fakultas Ilmu Kesehatan Universitas Ubudiyah Indonesia, Jl. Alue Naga Desa Tibang Kota Banda Aceh, Indonesia

Korespondensi: ulfa.feliz@gmail.com

Submitted: 15 November 2018, Revised: 18 April 2019, Accepted: 25 April 2019

https://doi.org/10.22435/jpppk.v3i1.868

\begin{abstract}
Abstrak
Target pemberian Air Susu Ibu (ASI) ekslusif adalah sebesar $80 \%$ sedangkan pencapaian di Kota Banda Aceh masih rendah yaitu $55,17 \%$. Perawatan payudara melancarkan sirkulasi darah dan mencegah tersumbatnya aliran susu sehingga memperlancar pengeluaran ASI dan mencegah permasalahan dalam menyusui. Survei awal di Puskesmas Jeulingke Kecamatan Syiah Kuala, Kota Banda Aceh diperoleh bahwa 6 dari 9 orang ibu hamil tidak melakukan perawatan payudara dan tenaga kesehatan hanya memberikan konseling perawatan payudara tanpa melakukan demonstrasi langkah-langkah perawatan payudara. Artikel ini bertujuan untuk mengetahui pengaruh demonstrasi terhadap keterampilan perawatan payudara pada ibu hamil trimester ketiga di wilayah kerja Puskesmas Jeulingke Kecamatan Syiah Kuala Banda Aceh. Penelitian ini bersifat eksperimen semu (quasi experiment) dengan pre-test post-test design. Dilakukan di wilayah kerja Puskesmas Jeulingke pada tanggal 25 Juni sampai dengan 2 Juli 2018. Besar sampel dalam penelitian ini sebanyak 31 orang dengan teknik purposive sampling. Pengumpulan data menggunakan lembaran observasi dan uji statistik menggunakan uji wilcoxon dengan taraf signifikansi $\alpha=0,05(\mathrm{C} 1=95 \%)$. Hasil analisis menunjukkan ada peningkatan yang signifikan sebelum dan sesudah diberikan demonstrasi perawatan payudara terhadap keterampilan ibu hamil dengan nilai $p=0,000$.
\end{abstract}

Kata kunci: Demonstrasi, Perawatan Payudara, Keterampilan

\section{Abstract}

The target of exclusive breastfeeding is $80 \%$ while the achievement in the city of Banda Aceh is still low at $55.17 \%$. The treatment of the breasts facilitates blood circulation and prevents clogging of the milk flow so as to facilitate the release of milk and prevent problems in breastfeeding. A preliminary survey at the Jeulingke Health Center in Syiah Kuala District, City of Banda Aceh revealed that 6 out of 9 pregnant women did not do breast care and health workers only provided breast care counseling without demonstrating breast care measures. This article aims to determine the effect of demonstrations on breast care skills in third trimester pregnant women in the working area of Jeulingke Community Health Center, Syiah Kuala District, Banda Aceh. This research was a quasi-experimental study with pre-test post-test design. It was carried out in the working area of the Jeulingke Community Health Center on June 25 to July 2, 2018. A total of 31 pregnant women was recruited using purposive technique sampling. Observation sheets were used to collect data. Data was 
analyzed using the Wilcoxon test with $5 \%$ significance level( $\alpha)$ and $95 \%$ confidence interval $(C 1=95 \%)$. It showed a significant $(p=0.0001)$ increase of breast care skills in the third trimester pregnant women after being given breast care demonstration.

\section{Keywords: Demonstration, Breast Care, Skills}

\section{Pendahuluan}

Air Susu Ibu (ASI) merupakan sumber makanan terbaik untuk bayi dan anak-anak dan menyusui adalah cara paling efektif untuk menjamin kesehatan anak dan kelangsungan hidup, secara global diperkirakan hanya $38 \%$ bayi yang diberikan ASI eksklusif selama enam bulan. ${ }^{1}$

Pemberian ASI eksklusif berdasarkan Peraturan Pemerintah Nomor 33 Tahun 2012 adalah ASI yang diberikan kepada bayi sejak dilahirkan selama enam bulan, tanpa menambahkan dan/ atau mengganti dengan makanan atau minuman lain kecuali obat, vitamin, dan mineral. Target pemberian ASI ekslusif 6 bulan adalah sebesar $80 \%$ sedangkan pencapaian di Kota Banda Aceh masih rendah. Walaupun ada peningkatan dari tahun 2012 (66,08\%) ke tahun 2013 (70,11\%), proporsi pemberian ASI eksklusif menurun lagi sejak tahun 2014 sampai dengan tahun 2016. Jumlah bayi usia 0 - 6 bulan pada tahun 2016 di Banda Aceh berjumlah 3.315 bayi dan yang mendapatkan ASI eksklusif sebanyak1.829 bayi $(55,17 \%)^{2,3}$

Perawatan payudara pada masa kehamilan adalah salah satu bagian penting yang harus diperhatikan sebagai persiapan untuk menyusui nantinya. Payudara perlu dipersiapkan sejak masa kehamilan sehingga bila bayi lahir dapat segera berfungsi dengan baik pada saat diperlukan. Perawatan payudara juga sangat membantu keberhasilan pemberian ASI dini, yang memengaruhi pemberian ASI eksklusif ${ }^{4}$.

Memberikan pengarahan tentang perawatan payudara kepada ibu hamil sedini mungkin adalah salah satu cara untuk mengatasi masalah kurangnya pemberian ASI eksklusif dengan melakukan health education melalui penyuluhan-penyuluhan pada ibu hamil yang disertai demonstrasi cara perawatan payudara yang benar sebelum dan setelah melahirkan, serta peragaan tentang perawatan payudara pada saat kontrol kehamilan dan kunjungan masa nifas, juga bisa melalui leaflet, alat peraga, poster-poster dan promosi melalui radio dan media lainnya. Upaya ini dapat meningkatkan kemampuan dan keterampilan ibu dalam perawatan payudara secara baik dan benar sebagai upaya preventif terhadap masalah menyusui sehingga proses menyusui dapat berjalan dengan lancar dan juga merupakan upaya meningkatkan derajat kesehatan ibu dan bayi. ${ }^{5}$

Perawatan payudara adalah salah satu upaya untuk memperlancar ASI, dimana dengan perawatan payudara dapat memperlancar sirkulasi darah dan mencegah tersumbatnya saluran susu. Perawatan payudara dilakukan sejak dini, bahkan tidak menutupi kemungkinan perawatan payudara sebelum hamil sudah mulai dilakukan. ${ }^{5}$

Pemenuhan kebutuhan psikologis akan tercapai ketika bayi menyusui pada ibunya. Peran ibu dalam memberikan ASI merupakan faktor yang sangat penting dalam membantu memenuhi kebutuhan ini. Peran ibu tersebut sesuai dengan teori model dalam keperawatan yaitu Maternal Role Attainment Becaming a Mother, dimana terdapat interaksi antara orang tua dan bayi pada saat dalam kandungan sampai diluar kandungan. ${ }^{6,7}$

Metode demonstrasi yang bersifat mengembangkan keterampilan peserta belajar (keterampilan mental maupun fisik atau teknis) merupakan metode memindahkan kondisi nyata ke dalam kegiatan atau ruang belajar di dalam situasi yang sesungguhnya. ${ }^{8}$ Metode demonstrasi adalah suatu strategi pengembangan dengan cara memberikan pengalaman belajar melalui perbuatan melihat dan mendengarkan diikuti dengan meniru pekerjaan yang didemonstrasikan. Metode ini juga merupakan metode yang digunakan untuk memperlihatkan sesuatu proses atau cara kerja suatu benda yang berkenaan dengan bahan pelajaran. ${ }^{9}$

Berdasarkan hasil pengambilan data awal di Puskesmas Jeulingke Kecamatan Syiah Kuala Banda Aceh pada tanggal 06 November 2017, jumlah ibu hamil yang berkunjung ke puskesmas dari bulan Januari sampai Oktober 2017 berjumlah 314 orang. Data ini merupakan data kunjungan ibu hamil yang berasal dari lima desa wilayah kerja yaitu Alue Naga, Tibang, Gampong Pineung, Jeulingke, dan Prada ke Puskesmas Jeulingke. Pada bulan Juni 2018, ibu 
hamil trimester ketiga berjumlah 31 orang yaitu: 3 orang dari Alue Naga, 4 orang dari Tibang, 8 orang dari Gampong Pineung, 9 orang dari Jeulingke, dan 7 orang dari Prada.

Setelah melakukan wawancara dengan beberapa ibu hamil yang berada di Puskesmas Jeulingke, diperoleh bahwa 6 dari 9 orang ibu hamil tidak melakukan perawatan payudara, dan setelah dilakukan wawancara dengan bidan didapatkan bahwa ada diberikan konseling perawatan payudara pada saat hamil dan menyusui, tetapi bidan tidak melakukan demonstrasi langkah-langkah perawatan payudara.

Penelitian ini dilakukan untuk mengetahui pengaruh demonstrasi terhadap keterampilan perawatan payudara pada ibu hamil trimester ketiga di wilayah kerja Puskesmas Jeulingke Kecamatan Syiah Kuala Banda Aceh tahun 2018.

\section{Metode}

Jenis penelitian yang digunakan dalam penelitian adalah yang bersifat eksperimen semu (Quasi Experiment) dengan menggunakan rancangan pretest-posttest design. Penelitian ini telah dilakukan di wilayah kerja Puskesmas Jeulingke Kecamatan Syiah Kuala Banda Aceh pada 25 Juni2 Juli Tahun 2018. Sampel penelitian ini adalah 31 ibu hamil trimester ketiga dari lima desa di wilayah kerja Puskesmas Jeulingke Kecamatan Syiah Kuala Banda Aceh. Pengambilan sampel menggunakan teknik purposive sampling dengan kriteri inklusi: ibu hamil trimester ketiga, hadir pada saat pengambilan data pretest dan posttest.

Data yang dikumpulkan dalam penelitian ini adalah data primer, diperoleh secara langsung dari responden berdasarkan observasi menggunakan panduan daftar tilik yang menilai teknik perawatan payudara selama hamil. Perlakuan yang diujikan berupa demonstrasi perawatan payudara. Sebelum diberikan demonstrasi, keterampilan ibu hamil dalam melakukan perawatan payudara diobservasi dengan menggunakan daftar tilik (pretest). Setelah itu, diberikan demonstrasi perawatan payudara dengan menggunakan phantom payudara. Kemudian ibu hamil melakukan kembali perawatan payudaranya. Keterampilan ibu hamil dalam melakukan perawatan payudara diobservasi lagi setelah 1 minggu setelah didemonstrasikan menggunakan daftar tilik yang sama (posttest).

Teknik perawatan payudara yang didemonstrasikan dan dinilai dalam daftar tilik diantaranya: 1) mencuci tangan sebelum melakukan perawatan payudara, 2) mengoleskan baby oil/ minyak ke payudara, 3) menyokong payudara kiri dengan tangan kiri, melakukan gerakan kecil dengan dua jari tangan kanan, mulai dari pangkal payudara dan berakhir dengan gerakan spiral pada daerah puting, dan melakukan hal yang serupa pada payudara sebelah kanan 4) membuat gerakan memutar sambil menekan dari pangkal payudara dan berakhir pada puting susu diseluruh bagian payudara kiri, dan melakukan hal serupa pada payudara sebelah kanan, 5) meletakkan kedua telapak tangan diantara dua payudara dan mengurut dari tengah ke atas sambil mengangkat kedua payudara dan lepaskan keduan ya dengan perlahan, 6) menyangga payudara kiri dengan tangan kiri, tangan kanan mengurut payudara dengan sisi kelingking dari arah pangkal payudara kearah puting susu, melakukan hal serupa pada payudara sebelah kanan, 7) kompres kedua payudara dengan waslap hangat selama 2 menit, kemudian mengganti dengan kompres dingin selama 1 menit, mengeringkan payudara dengan handuk kering dan memakai bra yang menopang payudara, 8) mencuci tangan.

Setelah dilakukan uji normalitas data menggunakan uji statistik Shapiro-Wilk didapatkan bahwa distribusi data pretest tidak normal yaitu $0,000(\mathrm{p}<0,05)$, maka digunakan uji wilcoxon untuk mengetahui pengaruh demonstrasi terhadap keterampilan perawatan payudara pada ibu hamil trimester ketiga di wilayah kerja Puskesmas Jeulingke, Kecamatan Syiah Kuala, Banda Aceh.

Instrumen yang digunakan dalam penelitian ini adalah daftar tilik. Pengolahan data dilakukan dengan cara analisa bivariat menggunakan uji wilcoxon dengan nilai normalitas distribusi data pretest 0,000 dan posttest 0,238 .

\section{Hasil}

Berdasarkan karakteristik umur responden pada Tabel 1 menunjukkan bahwa responden dengan umur 21-25 tahun sebanyak 10 orang (32,2\%), umur 26-30 tahun sebanyak 13 orang (41,9\%), 31-35 tahun sebanyak 8 orang $(25,8 \%)$. Berdasarkan karakteristik umur responden sebagian 
besar responden berumur 26-30 tahun (41,9\%).

Berdasarkan karakteristik pekerjaan responden pada Tabel 1 menunjukkan bahwa responden dengan pekerjaan sebagai ibu rumah tangga sebanyak 12 orang $(38,7 \%)$, wiraswasta sebayak 8 orang $(25,8 \%)$, pegawai negeri sipil (PNS) sebanyak 11 orang $(35,4 \%)$. Berdasarkan karakteristik pekerjaan responden sebagian besar responden adalah ibu rumah tangga yaitu sebesar $38,7 \%$.

\section{Tabel 1. Karakteristik Responden}

\begin{tabular}{lc}
\hline Karakteristik & Jumlah \\
\hline Umur (tahun) & \\
$21-25$ & 10 \\
$26-30$ & 13 \\
$31-35$ & 8 \\
Pekerjaan & \\
Ibu Rumah Tangga & 12 \\
Wiraswasta & 8 \\
Pegawai Negeri Sipil & 11 \\
\hline
\end{tabular}

\section{Analisa Bivariat}

Berdasarkan Tabel 2 dapat dilihat dari 31 responden yang memperoleh nilai median sebelum dilakukan demonstrasi terhadap perawatan payudara yaitu 0,00 dengan nilai terendah 0 dan nilai tertinggi 50, sedangkan setelah dilakukan demonstrasi terhadap perawatan payudara memperoleh nilai median sebesar 60,00 dengan nilai terendah 36 dan nilai tertinggi 89.

Hasil uji Wilcoxon didapatkan nilai $\mathrm{p}=0,000$, artinya ada peningkatan yang signifikan antara sebelum diberikan pelakuan (pretest) dengan setelah diberikan pelakuan (posttest) dalam keterampilan perawatan payudara pada ibu hamil trimester ketiga di wilayah kerja Puskesmas Jeulingke, Kecamatan Syiah Kuala, Banda Aceh.

Tabel 2. Karakteristik Tenaga Kesehatan Di Puskesmas

\begin{tabular}{lccc}
\hline \multirow{2}{*}{ Statistik } & \multicolumn{2}{c}{ Skor Keterampilan } & \multirow{2}{*}{ Nilai p } \\
\cline { 2 - 3 } & Pretest & Posttest & \\
\hline Median & 0,00 & 60,00 & 0,000 \\
Rentang & $0-50$ & $36-89$ & \\
\hline
\end{tabular}

\section{Pembahasan}

Hasil penelitian menunjukkan ada pengaruh demonstrasi terhadap keterampilan perawatan payudara pada ibu hamil trimester ketiga di wilayah kerja Puskesmas Jeulingke, Kecamatan Syiah Kuala, Banda Aceh.

Penelitian ini sejalan dengan penelitian yang dilakukan oleh Nanda (2015) yang menunjukkan bahwa hasil uji baca pengaruh pada posttest menyimpulkan demonstrasi berpengaruh terhadap pengetahuan ibu hamil di Puskesmas Keumala Kabupaten Pidie $(p=0,000)$. Dengan dilakukan demonstrasi berpengaruh terhadap pengetahuan perawatan payudara ibu hamil trimester ketiga. ${ }^{10}$

Demonstrasi merupakan metode yang digunakan untuk memperlihatkan sesuatu proses atau cara kerja suatu benda yang berkenaan dengan bahan yang ingin disampaikan. Metode demonstrasi lebih sesuai untuk mengajarkan bahan-bahan pelajaran yang merupakan suatu gerakan-gerakan, suatu proses maupun hal-hal yang bersifat rutin., ${ }^{8,11}$

Penelitian Permatasari menunjukkan bahwa setelah demontrasi teknik sadari, sebagian besar siswi melakukan sadari yaitu sebanyak 28 responden $(93,33 \%)$ dan terdapat 2 siswi yang tidak terampil dalam melakukan sadari $(6,67 \%)$ akan tetapi menjadi peningkatan nilai antara sebelum dan setelah dilakukan demonstrasi. Hasil penelitian yang dilakukan, demonstrasi ternyata memberikan pengaruh yang signifikan. Demontrasi dapat meningkatkan keterampilan dalam melakukan sadari. $^{12}$

Hasil penelitian Nurjannah (2012) menunjukkan bahwa ada peningkatan tentang pengetahuan sadari antara sebelum dan sesudah penyuluhan. Sebelum penyuluhan sebesar 6,456 ( $\mathrm{p}$ value $=0,000$ ), dan ada peningkatan pengetahuan setelah penyuluhan sebesar 48,252 (p.value $=0,000){ }^{13}$

Perawatan payudara adalah suatu tindakan untuk merawat payudara untuk memperlancar pengeluaran ASI, dengan melakukan perawatan yang tepat yang biasanya merupakan pengurutan dan pemijatan menggunakan bahan dan alat-alat, diharapkan ibu merasa lebih nyaman. Perawatan payudara dapat dilakukan dua kali sehari, yaitu pada saat mandi pagi dan mandi sore. ${ }^{5,14,15}$ 
Hasil penelitian Wahyu (2016) menunjukkan bahwa terdapat perbedaan pengetahuan pre dan post demonstrasi. Nilai mean pretest 3,20 dengan rentang 5-2, sedangkan skor pengetahuan kelompok post test didapatkan nilai mean 7,47 dan rentang 10-6 dengan $\mathrm{p}$ value 0,000 . Metode demonstrasi lebih efektif dibandingkan dengan metode ceramah dimana mean untuk demonstrasi $(7,47)$ atau lebih besar dari pada mean ceramah $(6,07)$ dengan $\mathrm{p}$ value $0,001 .^{8}$

Menurut asumsi peneliti dapat disimpulkan bahwa demonstrasi sangat berpengaruh dalam meningkatkan pelayanan asuhan kebidanan pada ibu hamil dalam teknik perawatan payudara selama hamil dengan adanya diberikan demonstrasi perawatan payudara oleh tenaga kesehatan maka adanya perubahan keterampilan terhadap cara perawatan payudara semasa hamil. Setelah dilakukan demonstrasi rata-rata ibu-ibu hamil di wilayah kerja Puskesmas memang dari dasar tidak mengetahui bagaimana cara perawatan payudara bahkan jarang mendapatkan informasi tentang bagaimana cara perawatan payudara selama hamil sehingga setelah dilakukan demonstrasi ini menjadi mengetahui bagaimana cara perawatan payudara semasa hamil dan mengetahui informasi-informasi yang dibutuhkan oleh ibu selama hamil.

\section{Kesimpulan}

Demonstrasi perawatan payudara untuk meningkatkan keterampilan perawatan payudara memberikan pengaruh meningkatkan pemberian ASI ekslusif pada ibu hamil trimester ketiga di wilayah kerja Puskesmas Jeulingke, Kecamatan Syiah Kuala, Banda Aceh tahun 2018.

\section{Saran}

Kepada petugas kesehatan diharapkan agar dapat menerapkan pelatihan rutin terhadap ibu hamil khususnya tentang perawatan payudara sehingga ibu hamil terampil dalam melakukan perawatan payudara selama masa kehamilannya.

\section{Daftar Rujukan}

1. WHO. Exclusive Breastfeeding For Six Months Best For Babies Everywhere. 2013 (Dikutip 5 Desember 2017. Diunduh dari: http://www. who.int/nutrition/topics/exclusivebreastfeed- ingforsixmonthsbestforbabieseverywhere/en/

2. Kementerian Kesehatan RI. Profil Kesehatan Indonesia 2015. Jakarta: Kemenkes RI; 2016.

3. Profil Kesehatan Aceh, 2016.

4. Syull K Adam, Martha D. Korompis, Getruida B H Alow. Perawatan Payudara Pada Masa Kehamilan Dan Pemberian Asi Eksklusif. 2016; ISSN : 2339-1731. Tersedia di: Jurnal Ilmiah Bidan (JIDAN).

5. Saryono P. Perawatan Payudara Edisi Keempat. Yogyakarta: Mitra Cendekia; 2014.

6. Maritalia D. Asuhan Kebidanan Nifas dan Menyusui. Editor Sujono Riyadi. Yogyakarta: Pustaka Belajar; 2012.

7. TomeyAM\&AlligoodMR.Nursing TheoristAnd Their Work (6th ed). Missouri: Mosby Inc; 2006.

8. Wahyu K. Efektivitas Penyuluhan Metode Ceramah Dan Demontrasi Terhadap Peningkatan Pengetahuan Tentang Breast Care Pada Ibu Menyusui Di Pustu Tibang Kecamatan Syiah Kuala Kota Banda Aceh. Skripsi. D-IV Kebidanan Fakultas Ilmu Kesehatan Universitas Ubudiyah Indonesia; 2016.

9. Hidayati A, Salawati T, Istiana S. Pengaruh Pendidikan Kesehatan Melalui Metode Ceramah Dan Demonstrasi Dalam Meningkatkan Pengetahuan Tentang Kanker Payudara Dan Ketrampilan Praktik Sadari (Studi pada Siswi SMAFutuhiyyah Mranggen Kabupaten Demak). 2012; Vol 1, No 1, p-ISSN: 2301-8372, e-ISSN: 2559-7081. Tersedia di: Jurnal Kebidanan Universitas Muhammadiyah Semarang

10. Seriami D. Efektifitas Demonstrasi Sadari Terhadap Peningkatan Pengetahuan Dan Keterampilan Remaja Putri Tentang Deteksi Dini Kanker Payudara Di SMA Negeri 3 Kuala Kecamatan Kuala Pesisir Kabupaten Nagan Raya. Skripsi. D-IV Kebidanan Fakultas Ilmu KesehatanUniversitasUbudiyahIndonesia;2016.

11. Lestari I. Pengaruh Penyuluhan Dengan Menggunakan Metode Demonstrasi Dan Bedside Teaching Terhadap Keterampilan Ibu Melakukan Pijat Bayi Di Tinjau Dari Paritas.. 2015; Vol 6, No 2 - Juni 2015. Tersedia di: Jurnal Kesehatan SAMODRA ILMU.

12. Permatasari D. Efektivitas Penyuluhan Dan Demontrasi Leaflet Sadari Terhadap Tingkat Pengetahuan Siswi SMA Negeri 2 Di Kecamatan 
Pontianak. 2013. Vol 3, No 1. Tersedia di: Jurnal Mahasiswa PSPD FK Universitas Tanjungpura.

13. Nanda M. Pengaruh Penyuluhan Perawatan Payudara Pada Masa Prenatal Terhadap Tingkat Pengetahuan Dan Sikap Ibu Primigravida Di Puskesmas Keumala Kabupaten Pidie. Skripsi. D-IV Kebidanan Fakultas Ilmu Kesehatan Universitas Ubudiyah Indonesia; 2015.
14. Nurrezki, dkk. Asuhan Kebidanan Nifas III. Yogjakarta: Nuha Medika; 2014. 15. Pratama L A. Efektifitas Pendidikan Kesehatan Terhadap Nilai Pengetahuan Mengenai Pemeriksaan Payudara Sendiri (Sadari) Pada Remaja Putri Di SMP Negeri 3 Tangerang Selatan. Skripsi. S1 Ilmu Keperawatan Fakultas Kedokteran dan Ilmu Kesehatan Universitas Islam Negeri Syarif Hidayatullah Jakarta; 2014. 